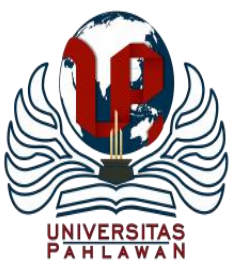

Jurnal Basicedu Volume 3 Nomor 4 Tahun 2019 Halaman 2050-2070

JURNAL BASICEDU

Research \& Learning in Elementary Education

https://jbasic.org/index.php/basicedu

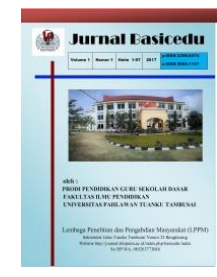

\title{
PENGARUH TEKNIK PERMAINAN PASS THE COMPLIMENT DALAM LAYANAN BIMBINGAN KELOMPOK TERHADAP PENINGKATAN SELF-ESTEEM SISWA SEKOLAH DASAR
}

\author{
Sulistyani Puteri Ramadhani \\ Universitas Trilogi Jakarta, Jakarta Selatan, Indonesia ${ }^{1}$ \\ Email : sulistyani@trilogi.ac.id
}

\begin{abstract}
Abstrak
Tujuan penelitian ini adalah untuk mengetahui pengaruh teknik permainan teknik permainan dalam layanan bimbingan kelompok terhadap peningkatan self-esteem pada siswa kelas VI Sekolah Dasar. Penelitian ini dilaksanakan di SDN Manggarai 17 Pagi dengan sampel penelitian adalah siswa kelas VI pada semester II tahun pelajaran 2017-2018. Sampel penelitian ini diambil menggunakan pemilihan sampel purposif. Penelitian ini menggunakan metode Kuasi-Eksperimen. Adapun teknik pengumpulan data dilakukan dengan menggunakan wawancara, diskusi kelompok, lembar ujian atau tes yang dilakukan setelah kegiatan diberikan. Lembar Penelitian untuk mengetahui tingkat self-esteem dengan teknik permainan siswa sekolah dasar. Hasil [enelitian Menunjukkan adanya pengaruh positif dari kegiatan bimbingan kelompok dengan teknik permainan 'pass the compliment' terhadap self-esteem siswa kelas VI SDN Manggarai 17 Pagi. Berdasarkan hasil uji hipotesis, diperoleh data bahwa: nilai asymp. Sig $=0,028<$ nilai Signifikan a $=0,05$ Hal ini menunjukkan bahwa $\mathrm{H}_{0}$ ditolak, dan $\mathrm{Hi}$ diterima. Sehingga dapat dimaknai, terdapat pengaruh yang signifikan pada peningkatan self-esteem responden setelah diberikan perlakuan bimbingan kelompok dengan teknik permainan "pass the compliment. Hasil peneltian kedua yaitu terdapat peningkatan self-esteem pada diri responden setelah mendapatkan perlakuan (treatment) bimbingan kelompok dengan teknik permainan pass the compliment. Implikasi hasil penelitian ini adalah dengan penggunaan teknik permainan pass the compliment dapat diterapkan untuk meningkatkan self-esteem sistwa pada belajar kelompok siswa sekolah dasar.
\end{abstract}

Kata Kunci : Self-esteem, bimbingan kelompok, teknik permainan, pass the compliment, sekolah dasar

@ Jurnal Basicedu Prodi PGSD FIP UPTT 2019

$\triangle$ Corresponding author :

Address :

Email :

ISSN 2580-3735 (Media Cetak)

Phone : 


\section{Pengaruh teknik permainan pass the compliment dalam layanan bimbingan kelompok terhadap}

peningkatan self esteem siswa sekolah dasar-Sulistyani Puteri Ramadhani

\section{PENDAHULUAN}

Seiring meningkatnya perkembangan usia anak kelas rendah, yaitu siswa Sekolah Dasar maka semakin bertambah luas lingkungan baik fisik dan non fisik yang akan mempengaruhinya, hal ini bisa jadi pemicu bagi anak untuk cenderung rendah dalam mengakui kemampuan diri (Departemen Pendidikan, 2012). Seperti layaknya perkembangan zaman, tumbuh kembang anak usia Sekolah Dasar pasti menyesuaikan dengan keadaan sekitar. Misalnya, dengan adanya gadget, ada sebagian anak yang tetap memilih bermain tradisional (tatap muka dan melibatkan kemampuan sosio emosional) namun ada juga anak sibuk sendiri dengan dunia gadget-nya, dengan segala dampak yang ada akibat kemajuan teknologi, tetap menjadi tanggung jawab orangtua untuk mengarahkan dan membimbing. Tetapi tidak semua orangtua menjalankan perannya dengan baik, hal ini tentu dapat mempengaruhi kemampuan anak untuk menghargai diri, bisa jadi semakin cepat atau justru semakin lambat. Hal ini memerlukan tindakan preventif sebelum menjadi permasalahan pada diri siswa.

Pada tataran pendidikan, khususnya bimbingan konseling hal ini menjadi salah satu pertimbangan untuk membantu siswa dalam upaya pengembangan pribadi. Sampai saat ini, di jenjang sekolah dasar tidak ditemukan posisi struktural untuk konselor. Namun demikian sesuai dengan tingkat perkembangan peserta didik usia sekolah dasar kebutuhan akan pelayanannya bukan tidak ada meskipun tentu saja berbeda dari ekspektasi kinerja konselor di jenjang sekolah menengah dan jenjang perguruan tinggi Dengan kata lain, konselor juga dapat berperan secara produktif di jenjang sekolah dasar, sebagai konselor kunjung yang diangkat pada setiap gugus sekolah dua konselor untuk membantu guru mengatasi perilaku mengganggu (disruptive behavior) sesuai keperluan, antara lain dengan pendekatan Direct Behavioral Consultation.

Hasil wawancara seperti halnya SDN Manggarai 17 Pagi, Manggarai 09 Pagi pernah mengadakan kegiatan bimbingan dan konseling kelompok untuk kelas VI, hai ini menunjukkan bahwa Bimbingan dan Konseling sudah mulai berperan di sekolah dasar tentu setelah disesuaikan dengan kebutuhan anak dan sekolah. Jika mengacu pada (Djiwandono, 2010) konsep BK Komprehensif, salah satu kegiatan BK adalah bimbingan kelompok. Menurut Djiwandono tujuan dari bimbingan dan kelompok pada anak adalah membantu dan mengembangkan kekuatan yang berpusat dan mengaktualisasikan diri mereka sehingga mereka dapat menghadapi dengan sukses untuk diri mereka dan lingkungannya. Selain itu, berkegiatan dalam kelompok dapat mengembangkan keterampilan sosial anak. Karena secara alami anak akan merasakan dinamika kelompok, seperti mulai mendengar informasi atau cerita anggota kelompok, mematuhi aturan kelompok, membangun komunikasi dengan anggota lain hingga anak mulai membuka diri.

Memang hanya sekolah dasar tertentu saja yang sudah mulai menerapkan layanan bimbingan dan konseling kelompok, diantaranya SDN Manggarai 17 Pagi, SDN Manggarai 09 Pagi,, dan SDN Manggarai 12 Pagi. Ketiga sekolah ini, terutama kepala sekolahnya mengakui dan menyadari betul bahwa peran bimbingan dan konseling sangat dibutuhkan bagi siswa sekolah 


\section{Pengaruh teknik permainan pass the compliment dalam layanan bimbingan kelompok terhadap peningkatan self esteem siswa sekolah dasar-Sulistyani Puteri Ramadhani}

dasar untuk memfasilitasi siswa dalam mencapai tugas perkembangannya secara fokus dan dapat berkolaborasi dengan guru kelas. Ternyata kelompok sangat bermanfaat dalam menangani masalah kepercayaan diri, karena kepercayaan diri yang buruk sering berasal dari kegagalan anak untuk menjalin interaksi yang positif dengan teman sebaya. Sejalan dengan pernyataan (Kathryn Gerald dan David Gerald, 2010), bahwa bentuk kepercayaan diri yang menjadi target kelompok adalah agar anak mampu menyamakan dirinya dengan teman- temannya dalam kelompok, menghargai dan meningkatkan kemampuan pribadi, kekuatan, dan keterampilannya, dan belajar cara bergaul yang lebih efektif.

Sejak usia dini, anak mulai membentuk citra, atau gambaran tentang dirinya. Gambaran atau citra ini umumnya mengacu pada konsep diri anak dan banyak dilandasi oleh cara anak diperlakukan orang-orang yang bermakna dalam kehidupannya. Perlu ditekankan bahwa konsep diri tidak sama dengan harga diri. Citra atau gambaran yang anak miliki tentang dirinya adalah konsep dirinya. Nilai yang mereka taruh pada citra ini adalah ukuran dari harga dirinya. Oleh karena itu, harga diri menurut (Kathryn, 2012) adalah indikasi seberapa besar anak menghargai dirinya. Harga diri tidak hanya sebatas bagaimana individu menilai dirinya tetapi juga merupakan nilai individu, persetujuan, penghargaan hadiah atau rasa suka terhadap dirinya sendiri.

Perkembangan kemampuan untuk menghargai diri anak tidak sama antara satu dengan yang lain, ada yang berkembang secara optimal dan ada yang belum berkembang secara optimal. Seperti anak yang memiliki harga diri negatif, biasanya cenderung akan memandang dirinya sebagai orang yang tidak berharga. Rasa tidak berharga tersebut dapat tercermin pada rasa tidak berguna dan tidak memiliki kemampuan baik dari segi akademik, interaksi sosial, keluarga, maupun keadaan fisiknya. Jangka panjang dari dampak harga diri yang negatif ini dapat membuat anak merasa mudah tersinggung dan marah sehingga dirinya menjadi tidak mampu menjalin hubungan dengan temannya.

Sesuai dengan teori (Erikson,2015) yang menyatakan bahwa masa pertengahan (usia sekolah dasar, 6-12 tahun) individu berada dalam tahapan antara tekun dan rendah diri (industry versus inferiority). Tidak ada saat lain yang lebih bersemangat atau antusiastis untuk belajar daripada akhir periode pengembangan imajinasi pada masa awal anak-anak. Guru seharusnya "Secara lembut tetapi tegas memaksa anak-anak untuk menguatkan bahwa seseorang dapat belajar apapun guna mencapai sesuatu yang tidak pernah ia pikirkan sendiri". Hal yang berbahaya ketika individu pada fase ini gagal dalam mengembangkan pengetahuan keterampilan diri, pengakuan lingkungan, atau mencapai prestasi maka individu akan merasa tidak kompeten, sehingga individu mengalami krisis dalam tahapan perkembangan selanjutnya.

Sebagai tindakan preventif, bimbingan kelompok dapat menjadi salah satu alternatif dari layanan Bimbingan Konseling yang dapat dilaksanakan untuk menyampaikan informasi kepada siswa sekolah dasar dan melatih siswa berinteraksi secara dinamis dengan sesama anggota kelompok. Mengingat subjek penelitian berada dalam tahap perkembangan usia sekolah 


\section{Pengaruh teknik permainan pass the compliment dalam layanan bimbingan kelompok terhadap peningkatan self esteem siswa sekolah dasar-Sulistyani Puteri Ramadhani}

dasar, permainan merupakan hal yang masih dekat dengan dunia anak sekolah dasar. Melalui teknik permainan pass the compliment, secara tidak langsung siswa akan belajar mengekspresikan diri, mengenal diri, mematuhi peraturan, dan melatih kreativitas siswa bahkan dapat meningkatkan selfesteem.

Hasil wawancara peneliti kepada wali kelas di SDN Manggarai 17 Pagi, menunjukkan data bahwa kecenderungan latar belakang ekonomi membuat beberapa siswa belum mampu menghargai diri dan orang lain, terutama dalam hal menonjolkan dan menerima diri serta realistis dalam percaya diri. Oleh karena itu, diperlukan upaya untuk meningkatkan dan mengembangkan self-esteem siswa sekolah dasar.

Self-esteem didefinisikan menurut (Wiliam, 1890) sebagai penghargaan diri yang terdiri dari perasaan dan emosi terhadap diri. Sebagai suatu hal yang ilmiah, self-esteem dikonseptualisasikan sebagai evaluasi diri (pretensi) dibagi dengan keberhasilan. William James percaya bahwa antara nilai-nilai, kesuksesan, dan kompetensi saling berhubungan. Individu memiliki perasaan dasar layak, nilai, menyukai, dan penerimaan. Oleh karena itu, James mengatakan self-esteem bersifat afektif. Tingkatan harga diri bersifat relatif sesuai kondisi objektif, seperti dalam menanggapi keberhasilan dan kegagalan dalam kehidupan seseorang.

Karakteristik self-esteem menurut (Guidon, 2009) pada seseorang dapat di klasifikasikan kedalam kategori sebagai berikut: Self-esteem positif, memiliki kecenderungan ciri-ciri sebagai berikut: 1) Berhasil atau berprestasi dalam bidang akademis aktif dan mampu mengekspresikan diri dengan baik, 2) Lebih bahagia dan efektif dalam menghadapi tuntutan lingkungan, 3) Menyukai tugas baru dan menantang serta tidak cepat bingung bila segala sesuatu berjalan diluar rencana, dengan kata lain individu yang memiliki self-esteem positif memiliki pengelolaan perasaan cemas dan tidak aman secara baik, 4) Tidak menganggap dirinya sempurna melainkan tahu keterbatasan diri dan mengharapkan adanya perbaikan atau kritik. 5) Memiliki nilai-nilai dan sikap yang demokratis serta orientasi realistis bukan berdasarkan fantasi.tidak terpengaruh pada penilaian orang lain, 6) akan mudah menyesuaikan diri dengan lingkungan baru, 7) Individu dapat menghargai diri apa adanya, tetapi bukan berarti kagum diri bahkan mengharapkan orang lain untuk kagum kepada diri individu tersebut. Salah satu cara untuk meningkatkan self-esteem melalui teknik permainan.

Games merupakan salah satu teknik dalam play therapy. Menurut (Kamus Besar Bahasa Indonesia, 2000,) permainan memiliki kata dasar main. Permainan memiliki arti "sesuatu yg digunakan untuk bermain; barang atau sesuatu yg dipermainkan; mainan". Menurut Santrock, games (permainan) adalah kegiatan yang dilakukan untuk memperoleh kenikmatan yang melibatkan aturan dan seringkali kompetisi dengan satu atau lebih orang.

Melalui permainan, pemain akan mencipiakan seduan kreativitas. Menurut (Anna Cattanach, 2016) berpendapat ketika anak bermain imajinatif, apapun permainannya mereka akan membayangkan dunia khayal (fiksi), hal ini membuat mereka memiliki rasa tentang dunia sesungguhnya. Tentunya dengan bimbingan 


\section{Pengaruh teknik permainan pass the compliment dalam layanan bimbingan kelompok terhadap peningkatan self esteem siswa sekolah dasar-Sulistyani Puteri Ramadhani}

therapis yang mampu mengasosiasikan setiap permainan dengan dunia nyata. Bermain adalah proses asimilasi informasi baru dan menjadi bagian dari diri sendiri. Dalam prosesnya merubah diri sendiri dan sudut pandang terhadap dunia.

Menurut (Rusmana, 2013), siswa-siswi yang bermain games harus memiliki toleransi untuk menerima batasan-batasan dalam berperilaku, bergiliran, mematuhi peraturan dan menerima kekalahan. Disamping itu dalam games diperlukan konsentrasi dan persistensi untuk mengikuti suatu permainan. Bermain games juga melibatkan suatu tantangan pribadi untuk menerapkan keterampilan-keterampilan seseorang. Maka pada pelaksanaannya games memerlukan kemampuan kognitif yang lebih besar.

Berdasarkan beberapa pengertian menurut ahli di atas, permainan merupakan kegiatan yang dijadikan alat bermain, melibatkan aturan atau batasan tertentu dan lebih bersifat kognitif karena di dalamnya akan terjadi proses belajar mamatuhi aturan, batasan, dan kreatifitas serta pada akhirnya anak bisa dapat saling menerima antara menang dan kalah. Pengaruh positif menurut . Bermain biasanya ditandai dengan tanda-tanda kesenangan dan kenikmatan tapi bahkan ketika itu tidak begitu menyenangkan, anak-anak masih menghargai aktivitas.

Berdasarkan hasil studi pendahuluan yang diperoleh dan latar belakang yang peneliti paparkan, Adakah pengaruh teknik permainan dalam layanan bimbingan kelompok terhadap peningkatan self-esteem siswa kelas III SDN Jatinegara 10 Pagi?

\section{METODE}

Penelitian ini dilaksanakan di SDN Manggarai 17 Pagi Kecamatan Tebet Jakarta Selatan. Subyek dalam penelitian ini adalah siswa kelas VI semester genap tahun pelajaran 2017/2018 sebanyak 6 siswa. Metode penelitian yang akan digunakan dalam penelitian ini adalah metode Kuasi-Eksperimen. Menurut (Paul Heppner, 2008) metode kuasi-eksperimen merupakan metode penelitian yang mirip dengan metode eksperimen murni namun lebih fleksibel karena tidak menggunakan random assigment kedalam kelompok penelitian.

Berdasarkan pernyataan di atas, beberapa hal penting mengenai metode penelitian kuasi eksperimen adalah perlakuan (treatment) terhadap subjek penelitian dalam kondisi yang terkendali, sengaja peneliti lakukan dalam rangka untuk mengetahui ada tidaknya pengaruh satu variabel terhadap variabel lain.

Jenis desain penelitian yang digunakan dalam penelitian pre-eksperimental kali ini adalah OneGroup Pretest-Posttest Design. Jenis desain ini digunakan untuk meneliti pada satu kelompok penelitian dengan melakukan satu kali pengukuran di awal sebelum adanya perlakuan kemudian setelah itu dilakukan pengukuran lagi. (Heppner, 2008) memaparkan bahwa dengan membandingkan pengujian pretest dan posttest, peneliti dapat menentukan perubahan yang terjadi setelah diberikan perlakuan

In Equation (C1) $\mathrm{O}_{1}$ is Nilai pre test selfesteem siswa kelas VI SDN Manggarai 17 Pagi sebelum diberi perlakuan. $\mathrm{X}$ is Treatment Bimbingan Kelompok menggunakan Teknik Permainan. $\mathrm{O}_{2}$ is Nilai post test self-esteem siswa 


\section{Pengaruh teknik permainan pass the compliment dalam layanan bimbingan kelompok terhadap peningkatan self esteem siswa sekolah dasar-Sulistyani Puteri Ramadhani}

kelas VI SDN Manggarai 17 Pagi sesudah diberi perlakuan. Peneliti melakukan pengujian awal pada kelompok yang dijadikan subjek penelitian. Pengujian awal ini dilakukan untuk mengetahui gambaran self-esteem siswa kelas VI SDN Manggarai 17 Pagi. Setelah itu peneliti memberikan treatment berupa layanan bimbingan kelompok dengan teknik permainan. Setelah perlakuan selesai diberikan, kemudian peneliti melakukan post test untuk mengetahui perubahan nilai atau peningkatan self-esteem siswa setelah diberikan treatment.

Populasi penelitian kali ini adalah siswa kelas VI SDN Manggarai 17 Pagi yang memiliki skor terendah (termasuk kategori self-esteem rendah) sebanyak 6 orang siswa. Berdasarkan hasil studi pendahuluan dan sebaran instrumen, enam orang siswa ini selalu mendapatkan skor terendah. Menurut (Sugiyono, 2008) populasi adalah wilayah generalisasi yang terdiri atas: obyekysubyek yang mempunyai kualitas dan karakteristik tertentu yang ditetapkan oleh peneliti untuk dipelajari dan kemudian diratik kesimpulan.

Teknik pengambilan sampling yang peneliti gunakan adalah purposive sampling tergolong dalam teknik pemilihan sampel nonprobabilitas. Menurut (Ulber Silalahi, 2015) pemilihan sampel purposif (bertujuan) merupakan pemilihan subjek yang ada dalam posisi terbaik untuk memberikan informasi yang dibutuhkan. Menurut (Arikunto, 2008) sampling purposive adalah teknik penentuan sampel dengan pertimbangan tertentu. Jumlah sampel yang diambil dalam penelitian adalah populasi yang terpilih dan memiliki kriteria, yaitu siswa dengan kategori self- esteem rendah supaya dapat semakin menunjukkan adanya perubahan pada variabel yang diukur.

Mengacu hasil studi pendahuluan dan sebaran instrumen kepada 35 siswa kelas VI SDN Manggarai 17 Pagi, terdapat enam orang siswa yang menjadi populasi karena termasuk ke dalam kategori self-esteem rendah. Peneliti menjadikan seluruh populasi yang berjumlah enam orang siswa ini menjadi sampel penelitian. Selain itu, berdasarkan hasil wawancara dengan guru kelas VI, enam orang siswa ini memang cenderung memiliki karakteristik self- esteem (harga diri) rendah. Berikut subjek yang menjadi sampel atau responden penelitian, yaitu: AP, FN, DVN, MR, ELS, RJL.

Pengujian hipotesis dilakukan untuk mengetahui perubahan atau peningkatan selfesteem antara sebelum dan sesudah perlakuan melalui teknik permainan. Dalam penelitian ini uji hipotesis dilakukan dengan menggunakan teknik Wilcoxon Match Pair Test. Teknik ini digunakan untuk menguji hipotesis komparatif dua sampel yang berkorelasi bila datanya berbentuk jenjang. Berikut rumus hipotesis Wilcoxon dalam (sudjana, 2008)

\section{HASIL DAN PEMBAHASAN}

Berdasarkan data dari instrumen self-esteem yang diberikan kepada enam (6) siswa SDN Jatinegara 10 Pagi mengenai self-esteem sebagai responden penelitian, diperoleh hasil data sebagai berikut: 
Tabel 1 Data Pre dan Post Test Self-esteem

\begin{tabular}{|c|c|c|c|}
\hline Kategori & $\begin{array}{c}\text { Rentang } \\
\text { Skor }\end{array}$ & $\begin{array}{c}\text { Frekuensi } \\
\text { Pre Test }\end{array}$ & $\begin{array}{c}\text { Frekuensi } \\
\text { Post - } \\
\text { Test }\end{array}$ \\
\hline Rendah & $<83,89$ & 6 & 0 \\
\hline Sedang & $\begin{array}{l}83,9- \\
120,39 \\
\end{array}$ & 0 & 6 \\
\hline Tinggi & $>120,40$ & 0 & 0 \\
\hline \multicolumn{2}{|c|}{ Jumlah } & 6 & 6 \\
\hline
\end{tabular}

Berdasarkan data hasil pre test selfesteem diketahui bahwa capaian skor keenam responden berada pada kategori cenderung rendah. Hal ini menunjukkan kondisi awal responden memiliki self-esteem cenderung rendah. Setelah diberikan layanan bimbingan kelompok dengan teknik permainan 'pass the compliment, responden diberikan post test selfesteem guna mengetahui peningkatan atau penurunan kategorisasi responden.

Berdasarkan data hasil post test, responden mengalami peningkatan self-esteem. Hasil capaian skor seluruh responden menunjukkan bahwa kondisi responden meningkat menjadi termasuk kategori sedang. Meski naik hanya satu kategori, namun perubahan ini menjadi sebuah potensi yang baik untuk responden tetap dapat meningkatkan selfesteem. Lebih jelas dapat dilihat dalam gambar grafik berikut:

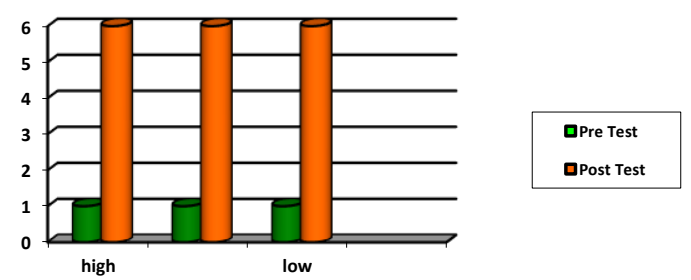

Grafik 1. Pre Test- post Test keseluruhan
Berdasarkan hasil perhitungan analisis secara keseluruhan dapat disimpulkan bahwa terdapat peningkatan self-esteem dalam diri responden, yang semula termasuk kategori paling rendah kemudian menjadi siswa yang cenderung memiliki self-esteem dengan kategori sedang. Hal ini dibuktikan oleh sudut pandang responden saat menilai diri dan perilaku responden sudah mulai menunjukkan perubahan, seperti; mulai mengenai dan menerima potensi kelebihan dan kekurangan diri serta dapat yakin saat membuat keputusan secara mandiri.

Berikut hasil penelitian secara rinci berdasarkan aspek self-esteem:

Self-efficacy menjadi aspek yang pertama dalam teori self-esteem menurut Natanhiel Branden. Dalam aspek ini memiliki empat indikator, yaitu ; (1) Yakin akan kemampuan berpikir, memahami, belajar, memilih dan membuat keputusan, (2) yakin akan kemampuan diri untuk memahami fakta dan lingkungan mengenai kesenangan dan kebutuhan dirinya, (3) kepercayaan diri, dan (4) kemandirian.

Tabel 2

Data Pre-Post Test pada Aspek Selfefficacy

\begin{tabular}{|l|l|l|l|}
\hline $\begin{array}{l}\text { Kategorisas } \\
\mathrm{i}\end{array}$ & Rentang Skor & $\begin{array}{l}\text { Frekuensi } \\
\text { Pre Test }\end{array}$ & $\begin{array}{l}\text { Frekuensi } \\
\text { Post Test }\end{array}$ \\
\hline Rendah & $<46,50$ & 5 & 0 \\
\hline Sedang & $46,51-67,66$ & 1 & 6 \\
\hline Tinggi & $>67,68$ & 0 & 0 \\
\hline Jumlah & & 6 & 6 \\
\hline
\end{tabular}




\section{Pengaruh teknik permainan pass the compliment dalam layanan bimbingan kelompok terhadap}

peningkatan self esteem siswa sekolah dasar-Sulistyani Puteri Ramadhani

Tampak bahwa capaian skor seluruh responden sebelum diberi perlakuan memiliki selfesteem yang berada pada kategori cenderung rendah. Setelah diberikan perlakuan bimbingan kelompok dengan teknik permainan "pass the compliment', tampak bahwa beberapa responden mengalami peningkatan dan terdapat satu responden yang tidak mengalami peningkatan. Kondisi awal saat pre test, untuk kategori selfesteem cenderung rendah sejumlah enam (6) siswa, kemudian berdasarkan data hasil post test terdapat jumlah frekuensi yang berada pada kategori rendah tidak ada dan enam (6) responden dengan kategori sedang. Dapat dilihat dalam gambar grafik dibawah ini:

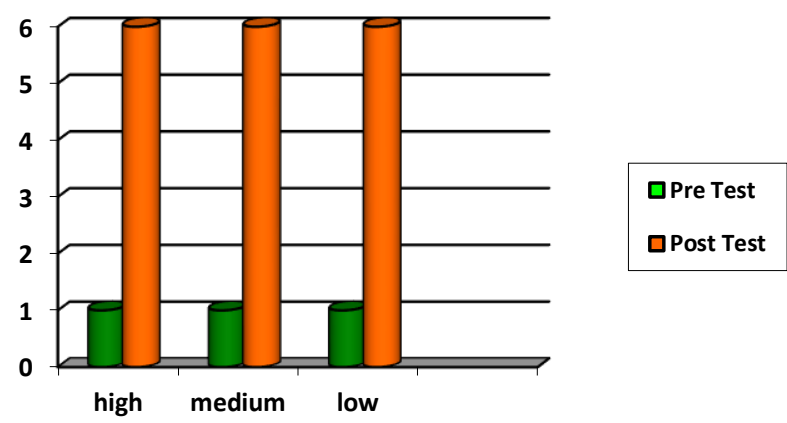

Grafik 2. Perbandingan Pre-Post Test dalam Aspek 1

Hasil analisis menunjukkan bahwa seluruh responden menunjukkan peningkatan kategorisasi self-esteem. Self-respect menjadi aspek yang kedua dari self-esteem, memiliki indikator, yaitu ; (1) Keyakinan pada nilailvalue diri sendiri, (2) Sikap Afirmatif terhadap kebenaran hidup dan menjadi bahagia, (3) Kenyamanan dalam menegaskan pikiran, keinginan, dan kebutuhan, dan (4) Perasaan senang dan pemenuhan akan rasa senang itu adalah hak dasar.

Tabel 3

Data Pre-Post Test pada Aspek Self-respect

\begin{tabular}{|l|l|l|l|}
\hline $\begin{array}{l}\text { Kategorisas } \\
\text { i }\end{array}$ & $\begin{array}{l}\text { Rentang } \\
\text { Skor }\end{array}$ & $\begin{array}{l}\text { Frekuensi } \\
\text { Pre Test }\end{array}$ & $\begin{array}{l}\text { Frekuens } \\
\text { Test Post }\end{array}$ \\
\hline Rendah & $<36,09$ & 6 & 1 \\
\hline Sedang & $36,08-54,03$ & 1 & 6 \\
\hline Tinggi & $>54,04$ & 1 & 1 \\
\hline Jumlah & 6 & 6 \\
\hline
\end{tabular}

Hasil analisis pada aspek ini saat kondisi awal sebelum diberi perlakuan bimbingan kelompok dengan teknik permainan "pass the compliment", bahwa seluruh responden memiliki self-esteem cenderung rendah. Setelah diberikan perlakuan, seluruh responden mengalami peningkatan capaian skor post test sehingga responden menjadi termasuk kategori sedang.

Secara jelas dapat dilihat dalam gambar grafik sebagai berikut:

Dari tabel di atas, menunjukkan bahwa kondisi awal sebelum diberi perlakuan terdapat enam responden berada dalam kategori rendah, dan tidak ada responden yang berada pada tingkat kategori sedang bahkan tinggi.

Responden dengan inisial AP mengalami peningkatan self- esteem sangat baik. Sebelum diberi perlakuan, AP memperoleh skor sebesar 79 termasuk kategori self-esteem cenderung rendah kemudian setelah diberi perlakuan, AP mengalami peningkatan capaian skor menjadi sebesar 111 termasuk kategori self-esteem cenderung sedang Berdasarkan hasil analisis, bahwa AP memiliki potensi cukup baik dalam 


\section{Pengaruh teknik permainan pass the compliment dalam layanan bimbingan kelompok terhadap peningkatan self esteem siswa sekolah dasar-Sulistyani Puteri Ramadhani}

bidang akademik hanya saja AP sebagai murid pindahan dari daerah, merasa ragu dengan kemampuan yang dimiliki untuk berkompetisi dengan siswa sekelasnya.

Responden dengan inisial FN mengalami peningkatan self- esteem cukup baik. Berdasarkan hasil pre test FN memperoleh skor sebesar 77 termasuk kategori rendah, kemudian hasil post test menunjukkan bahwa FN mengalami peningkatan capaian skor sebesar 103 dengan kategori sedang. Tampak dari perilaku FN yang berubah ialah pada pertemuan kelima yaitu FN sudah mulai mampu menentukan keputusan sendiri tanpa mengikuti teman yang lain.

Responden dengan inisial DVN mengalami peningkatan self- esteem yang positif. Berdasarkan capaian skor pre test DVN memperoleh skor sebesar 72 , kemudian naik 32 poin saat diberikan post test DVN memperoleh skor sebesar 104 dengan kategori sedang. Meski kenaikkan skor DVN tidak terlalu besar, tetapi DVN sudah mulai berani mengencangkan volume suara ketika bercerita dalam kelompok.

$$
\text { Responden dengan inisial MR }
$$
berdasarkan hasil pre test memperoleh skor sebesar 75 dengan kategori rendah, kemudian berdasarkan data hasil post test MR mengalami peningkatan dalam capaian skor, yaitu sebesar 102 termasuk kategori sedang.

$$
\text { Responden dengan inisial ELS }
$$
meengalami peningkatan self-esteem cukup baik. ELS memperoleh skor 71 pada kondisi pre test termasuk kategori rendah, skor ELS merupakan skor pre test yang paling rendah diantara kelompok penelitian ini. Setelah diberi perlakuan, sesuai data hasil post test ELS memperoleh capaian skor sebesar 98 termasuk kategori sedang. ELS berhasil naik sebanyak 27 poin dalam hitungan capaian skor.

Responden dengan inisial RJL mengalami peningkatan self- esteem yang positif. Berdasarkan capaian skor pretest RJL memperoleh skor sebesar 75, kemudian naik 26 poin saat diberikan post test RJL memperoleh skor sebesar 101 menjadi kategori sedang. Untuk lebih jelas dalam melihat peningkatan capaian skor setiap responden, berikut gam bar grafiknya:

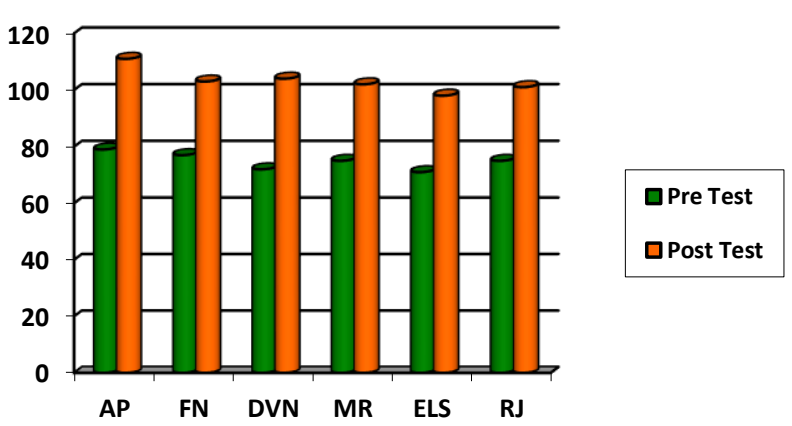

Grafik 3. Capaian Skor Tiap Responden

Sehingga dapat dirata-ratakan seluruh responden mengalami peningkatan secara positif. Saat kondisi awal, responden melakukan pre test dengan capaian skor rata-rata sebesar 74,83 poin, termasuk kategori self-esteem cenderung rendah. Setelah diberi perlakuan bimbingan kelompok dengan teknik permainan "pass the compliment, responden mengisi post test dengan capaian skor rata-rata 103,17 , termasuk kategori self-esteem sedang. Dapat dilihat dalam gambar grafik, dibawah ini: 


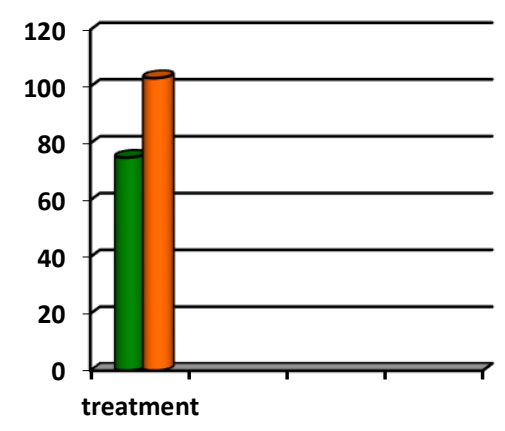

$\square$ Before Treatment

$\square$ After Treatment

Grafik 4. Capaian Rata- rata Skor Tiap Responden

Analisis juga dilakukan setiap perkembangan individu, dapat dilihat tabel dibawah ini :

Tabel 4

Data Capaian Skor Pre test dan Post Test Setiap responden

\begin{tabular}{|l|l|l|l|l|l|}
\hline No & $\begin{array}{l}\text { Respon } \\
\text { den }\end{array}$ & $\begin{array}{l}\text { Score } \\
\text { Before } \\
\text { Treatment }\end{array}$ & $\begin{array}{l}\text { Categ } \\
\text { ory }\end{array}$ & $\begin{array}{l}\text { Acore } \\
\text { After } \\
\text { Treatmeny } \\
\text { t }\end{array}$ & Categor \\
\hline 1 & AP & 79 & Low & 111 & High \\
\hline 2 & FN & 77 & Low & 103 & Medium \\
\hline 3 & DVN & 72 & Low & 104 & Medium \\
\hline 4 & MR & 75 & Low & 102 & Medium \\
\hline 5 & ELS & 71 & Low & 98 & Medium \\
\hline 6 & RJL & 75 & Low & 101 & Medium \\
\hline Average & 74,83 & & 103,17 & \\
\hline
\end{tabular}

Total skor rata-rata setelah diberikannya perlakuan pada responden adalah 103,17, hal ini menunjukkan adanya peningkatan pada skor ratarata self-esteem sebesar 28,34 poin dari kondisi awal sebelum diberikannya perlakuan terhadap responden.

Pembentukan. Pada kegiatan bimbingan kelompok ini, peneliti sebagai pemimpin kelompok. Sebelum memasuki tahap pembukaan, tentu peneliti merancang perencanaan dan persiapan. Peneliti melakukan seleksi anggota kelompok berdasarkan data hasil pre test instrumen self- esteem dan wawancara dengan guru wali kelas II dan III. Berdasarkan hasil data pre test terdapat enam siswa yang termasuk kategori self- esteem rendah, namun guru wali kelas merekomendasikan satu responden $\mathrm{ZH}$, tetapi satu siswa ini tidak bersedia mengikuti kegiatan karena tidak mendapatkan izin orangtua dengan alasan ada les sepulang dari sekolah. Hanya enam orang siswa yang bersedia sukarela menjadi responden dalam penelitian kali ini, yaitu: AP, FN, DVN, MR, ELS, dan RJL.

Tahap Pertemuan Pertama. Pada pertemuan pertama ini, pemimpin dan anggota kelompok saling berkenalan, kemudian pemimpin kelompok mengungkapkan tujuan, asas, cara, dan apersepsi mengenai kegiatan bimbingan kelompok. Sampai pada kelompok memahami tujuan akhir dari kegiatan bimbingan konseling ini ialah membangun dan meningkatkan harga diri. hasil kesepakatan anggota kelompok berupa: bersedia mengikuti kegiatan bimbingan kelompok hingga akhir terkecuali jika sakit, jumlah keanggotaan tidak berkenan bertambah hingga selesai program, anggota kelompok bersedia menjaga asas kerahasiaan dan kesukarelaan untuk bercerita, serta saling menghargai jika ada yang berbicara maka yang lain mendengarkan. Selanjutnya peneliti memasuki tahap peralihan, pada tahap ini pemimpin seolah membangun 'jembatan' antara tahap pertama dan tahap selanjutnya. Pemimpin kelompok sambil mengamati kenyamanan dan keterlibatan anggota kelompok. Mengacu pada teori Play Theraphy, dalam games (teknik permainan) diperlukan tahap warm up. Dalam tahap peralihan ini peneliti memasukkan 


\section{Pengaruh teknik permainan pass the compliment dalam layanan bimbingan kelompok terhadap peningkatan self esteem siswa sekolah dasar-Sulistyani Puteri Ramadhani}

permainan si laris manis, 'Guess What It Is' dan 'Seven Booms'. Permainan 'guess what it is' bertujuan untuk membangkitkan keberanian dan kepercayaan diri dalam berpikir, anggota kelompok diminta untuk memperkenalkan nama kemudian mempraktekan gerakan hewan kesukaannya, lalu anggota kelompok lain menebak gerakan hewan yang dipraktekan oleh anggota kelompok yang sedang memperkenalkan diri tersebut. Permainan 'seven booms' ini bertujuan untuk membangkitkan fokus pada anggota kelompok sebagai pengantar memasuki tahap kegiatan. Semula permainan yang direncanakan ialah seven booms, namun anggota belum mampu mengingat kelipatan tujuh, sehingga pemimpin dan anggota kelompok menyepakati untuk bermain 'three booms' dan meningkat lagi menjad 'five booms'.

Memasuki kegiatan inti, pemimpin kelompok mendorong anggota kelompok untuk bercerita tentang suasana perasaan dan pikiran yang sedang dirasakan dan dipikirkan, baik yang mengganggu maupun tidak. Sebagai kegiatan bimbingan kelompok tugas, pertemuan kali ini mengangkat tema 'Darimana Aku berasal' dengan topik pembahasan 'Aku dan Keluargaku'.

Seluruh anggota kelompok bercerita tentang pekerjaan orangtua dan suasana di rumah masingmasing, semua bersedia bercerita meski awalnya RJL dan ELS adalah anggota kelompok yang paling malu untuk bercerita. Ada lima anggota kelompok yang mengakui bahwa suasana di rumah kadang membuat mereka tak nyaman karena harus mendengar orangtua bertengkar dan akhirnya mereka juga terkena marah. Lain dengan cerita FN, FN mengakui bahwa orangtuanya selalu diberikan apa saja yang ia mau namun ia jarang bertemu dengan orangtua karena kedua orangtua sibuk bekerja. Saat salah satu anggota kelompok selesai bercerita, pemimpin kelompok menstimulus anggota kelompok lain menanggapi dan bertanya kepada yang bercerita.

Dari pertemuan pertama, responden sudah mulai menentukan dan memutuskan peraturan kelompok yang harus ditaati bersama, kemudian seluruh responden mulai mengerti peran diri dalam kelompok dan tujuan akhir dari kegiatan bimbingan kelompok ini. Tidak hanya itu, responden semula malu dengan keberadaan dirinya dalam kelas karena latar belakang keluarga yang kurang sempurna menurut mereka, saat anggota kelompok saling bercerita dan menanggapi serta sedikit cerita singkat dari pemimpin kelompok mengenai cerita orang sukses yang berasal dari keluarga kurang mampu "Yohanes Surya". Pemimpin kelompok menceritakan bahwa Yohanes Surya sejak kecil ia suka berhitung, bukan sebagai tokoh ahli fisika dan kimia karena untuk menghindari kebingungan pada keenam responden. Pemimpin kelompok menekankan cerita kecil Yo merupakan anak seorang penjual bakpau, namun hal itu tidak menghentikan langkahnya dalam menggapai impian, kerja keras dan kerja cerdasnya berbuah hasil yang manis saat ini. Pada akhir kegiatan anggota kelompok berhasil menyimpulkan bahwa latarbelakang keluarga bukan penghalang menuju kesuksesan seseorang. Mengutip pernyataan AP, "kadang saya suka sedih kalo orangtua gak ngehargain usaha saya, si mama gak tau aku susah banget bisa kenalan di kelas bam". Keenam responden memberikan pernyataan dan saling 


\section{Pengaruh teknik permainan pass the compliment dalam layanan bimbingan kelompok terhadap peningkatan self esteem siswa sekolah dasar-Sulistyani Puteri Ramadhani}

menanggapi, dan pemimpin kelompok meyakinkan bahwa setiap responden harus percaya kemampuannya akan memahami lingkungan keluarga, seburuk apapun kondisinya tidak dijadikan sebagai penghalang dalam mencapai prestasi.

Mengingat bahwa pertemuan ini memiliki indikator berupa deskriptor salah satu aspek dari self-efficacy, yaitu percaya akan kemampuannya untuk memahami lingkungannya. Efikasi diri menekankan pada komponen keyakinan diri yang dimiliki seseorang dalam mengahadapi situasi akan datang yang mengandung kekaburan, tidak dapat diramalkan, dan sering penuh dengan tekanan. Seseorang yang memiliki self-efficacy yang baik, akan merasa dirinya selalu siap dan sigap dalam menyelesaikan permasalahan tanpa adanya keraguan tentang keadaan diri. Dia tidak akan memikirkan dirinya dengan orang lain, namun meyakini dirinya mampu seperti orang lain. Maka dari itu, keenam responden harus mengenal dan menerima keadaan keluarganya saat ini, sebagai persiapan kelak akan siap dan sigap dalam menyelesaikan masalah terkait keadaan ekonomi keluarga.

Tahap Pertemuan Kedua. Tahap ini pemimpin dan anggota kelompok sepakat untuk mengangkat tema "mengenal diri" melalui teknik permainan "Pass the Compliment". Sebelum memulai permainan, pemimpin kelompok mengajak anggota kelompok bermain three booms sebagai pengantar anggota kelompok agar fokus. Selanjutnya anggota kelompok diminta untuk mengisi lembar kerja, anggota kelompok menuliskan kelebihan dan kekurangan pada lembar kerja tersebut, kemudian berputar kepada yang lain saling meniiai kelebihan dan kekurangan temannya, sehingga lembar kerja kembali pada si pemilik. Anggota kelompok mulai menyadari hal yang menjadi kelebihan dan kekurangan (potensi) diri dan juga pengakuan dari beberapa temannya, sehingga pada tahap ini semua anggota kelompok berpendapat dan saling menanggapi tentang kebenaran penilaian satu sama lain.

Selama kegiatan anggota kelompok mulai mampu menyebutkan kelebihan dan kekurangan diri dan teman meski hanya dua poin saja, tetapi hal ini menunjukkan bahwa anggota kelompok (sesuai tahap perkembangannya) sudah mulai berani menyampaikan dan menegaskan pikiran. Di tengah permainan, pemimpin kelompok mendapati FN melirik teman sebelahnya, agar memastikan anggota kelompok tidak saling meniru anggota kelompok diminta untuk duduk berjauhan.

Sesuai dengan tujuannya, permainan ini berhasil membuat anggota kelompok menyadari kelebihan dan kekurangan masing-masing, percaya diri dengan kelebihan yang dimiliki, dan tidak rendah diri dengan kekurangannya. Pada akhir sesi pemimpin kelompok menegaskan bahwa anggota kelompok perlu meyakini bahwa dengan kelebihan dan kekurangan yang dimiliki tetap dapat menjadi orang baik dan tentu berguna bagi orang lain, khususnya lingkungan terdekat seperti keluarga dan warga sekolah. Pertemuan kali ini mengangkat tema self-respect, Branden menyatakan bahwa self-respect harus dibangun sejak dini sehingga anak sadar akan kekuatannya untuk bertindak secara bertangung jawab. Hal ini dimulai dengan melatih anak agar mampu yakin bahwa dirinya orang baik sehingga dengan kebaikannya anak dapat merasa berguna untuk 


\section{Pengaruh teknik permainan pass the compliment dalam layanan bimbingan kelompok terhadap peningkatan self esteem siswa sekolah dasar-Sulistyani Puteri Ramadhani}

orang lain. Indikator ini telah tercapai pada sesi pertemuan kedua ini, hanya saja pemimpin kelompok butuh berkolaborasi dengan guru kelas bahkan orangtua untuk membudayakan sikap memuji hasil karya dan perbuatan baik anak, hal sederhana ini mampu memberikan persepsi pada diri anak bahwa dirinya baik.

Tahap Pertemuan Ketiga. Memasuki fase warming up, pada pertemuan ketiga ini saat memasuki tahap peralihan pemimpin kelompok mengajak anggota kelompok bermain permainan koboy mexico, bertujuan sebagai pengantar fokus anggota kelompok menuju kegiatan. Selanjutnya pemimpin kelompok mulai menjelaskan aturan main dari permainan "Pass the Compliment' sampai anggota kelompok paham betul. Masingmasing anggota kelompok menulis kelebihan, kekurangan, cita-cita dan usaha dalam kertas kemudian kertas tersebut dilipat dan disimpan di tengah-tengah kita, salah satu anggota kelompok mengambil kertas secara acak dan dengan mata terpejam kemudian ia harus menebak siapa si penulis tersebut.

Selama permainan berlangsung ada anggota yang berhasil menebak dan ada juga yang belum berhasil menebak. Anggota yang pertama menjawab ialah AP, kemudian RJL dan MR merupakan anggota kelompok yang berhasil menebak. Pada akhir kegiatan pemimpin kelompok menanyakan makna dari permainan 'pass the compliment' ini kepada seluruh anggota, kemudian semua saling menanggapi. Ada satu anggota kelompok, yaitu AP mengungkapkan pemyataan: "kok saya seneng ya kalo temen tahu hobby saya, saya ngerasa diperhatiin". Pemimpin tetap menegaskan makna dari permainan 'pass the compliment.

Ada pertemuan ini peneliti menemukan fakta, bahwa anggota kelompok memiliki kecenderungan berkata kasar (tidak selayaknya untuk seusia sekolah dasar) kemudian peneliti menugaskan kepada anggota kelompok untuk saling mencatat jika sesama anggota berkata kasar. Anggota kelompok sepakat dan akan membahasnya pada pertemuan selanjutnya. Hal ini juga sebagai stimulus bahwa dirinya berhak mendapat perhatian dari oranglain, tentu mulai dari perbuatan baik yang sederhana.

Pertemuan Keempat. Pada pertemuan ini pemimpin kelompok meminta anggota kelompok untuk mengingat kegiatan apa yang telah dilakukan dan mendapat informasi apa saja dari pertemuan sebelumnya. Anggota kelompok ingat betul, bahwa kita memiliki kesepakatan untuk saling mencatat jika sesama anggota ada yang berkata kasar. FN menjadi anggota kelompok dengan catatan terbanyak, namun sayang pada pertemuan ini FN tidak masuk karena sakit. Pemimpin kelompok sedikit membahas mengenai kebiasaan berkata kasar, anggota kelompok saling bertukar pendapat bahwa semua merasa sudah terbiasa karena meniru orangtua sehingga sulit untuk menghilangkan kebiasaan berkata kasar, hanya saja anggota kelompok mau mengurangi dan saling mengingatkan di kelas.

Pada saat tahap peralihan, pemimpin kelompok mengajak anggota kelompok bermain 'simphaty ball, bertujuan untuk mengajak anggota kelompok agar memberikan informasi atau pendapat dengan cara yang baik dan mudah 'ditangkap' oleh orang lain sehingga orang lain 


\section{Pengaruh teknik permainan pass the compliment dalam layanan bimbingan kelompok terhadap peningkatan self esteem siswa sekolah dasar-Sulistyani Puteri Ramadhani}

dapat menerima informasi atau pendapat kita juga baik. Misalnya: kita mau berpendapat namun suara kita terdengar kecil dan wajah kita tampak ragu, terlihat tidak meyakinkan maka informasi dan pendapat kita kurang disimak dengan baik. RJL bersuara bahwa sehari-hari ELS, DVN, dan FN selalu menampilkan pribadi yang disebutkan, pemimpin kelompok menstimulus anggota kelompok lain untuk menanggapi dan mendengarkan cerita ELS, DVN, dan FN.

Memasuki tahap kegiatan inti, pemimpin kelompok menjelaskan kembali aturan main permainan pass the compliment, hanya saja kelebihan dan kekurangan diri yang ditulis tidak boleh sama dengan pertemuan sebelumnya. Pada pertemuan ini anggota kelompok diminta untuk menuliskan prestasi yang telah diraih sekecil apapun dan dalam bidang apapun. Permainan cukup berjalan dengan suasana riang, karena beberapa kali anggota menertawai prestasi yang di tulis seperti rnenang lomba makan kerupuk saat perlombaan 17 Agustus di daerahnya masingmasing.

Pemimpin kelompok mengajak anggota kelompok mengakui dan menyadari bahwa mereka pernah mencapai sebuah prestasi, jika kemarin mendapatkan prestasi di bidang A, saat ini anggota kelompok sudah mulai mengetahui kelebihan diri masing-masing sehingga anggota kelompok bisa lebih optimal dalam mencapai prestasi. Ketika pemimpin menanyakan pndapat anggota kelompok, MR langsung menanggapi bahwa dirinya nerasa yakin akan mampu bermain bola dan ia suka bola bukan karena crang lain, dia merasa harus lebih giat berlatih. Di susul pernyataan DVN, "api lu jangan maen bola muluuu, belajarnya juga jangan ditinggalin". AP can ELS mengiyakan pernyataan DVN. Sudah mulai tampak bahwa ikatan psikologis di antara anggota kelompok sudah terbentuk dan terlihat bahwa aiggota kelompok sudah berani menegaskan pikirannya masing-masing. Nelalui dinamika kelompok pada pertemuan kali ini, sudah mulai tampak leenam responden mampu menonjolkan dan menerima diri dalam kelompok.

Pertemuan Kelima. Tahap ini pemimpin kelompok mengingatkan kembali hasil pertemuan sebelumnya. Selanjutnya pemimpin kelompok mengajak anggota kelompok untuk bermain permainan tupai dan pemburu, permainan ini bertujuan untuk semakin mengakrabkan sesama anggota kelompok. selain itu, permainan ini juga mengajarkan cara survive jika menghadapi rintangan dan hal ini menjadi salah satu deskriptor di dalam teori self-esteem menurut Branden. Kemudian anggota kelompok kembali bermain permainan "pass the compliment. Kali ini seluruh anggota diminta untuk menulis dengan jujur, kelebihan dan kekurangan yang selama ini sudah diakui oleh diri sendiri, teman-teman, atau bahkan guru dan orangtua. Anggota kelompok sedikit lancar mengisi, karena mereka tinggal mengingat dari permainan 'pass the compliment' sebelumnya.

Setelah itu anggota kelompk diminta untuk menggambar dengan anggota tubuh selain tangan. Tampak seluruh anggota kelompok bergembira, semua merasa kesulitan untuk menggambar dengan mulut bahkan ada yang mencoba menggunakan kaki. Setelah melihat hasil anggota kelompok diminta untuk menarik makna dari kegiata tersebut. Semua anggota mengatakan betapa sulitnya menggambar jika tidak 


\section{Pengaruh teknik permainan pass the compliment dalam layanan bimbingan kelompok terhadap peningkatan self esteem siswa sekolah dasar-Sulistyani Puteri Ramadhani}

menggunakan tangan. Selanjutnya pemimpin kelompok menayangkan video "Nick Fujivic", semua anggota kelompok diminta untuk menyampaikan pendapat setelah menyimak tayangan. Ada satu anggota kelompok menyatakan bahwa "kita punya anggota tubuh yang sempurna, gak boleh kebanyakan ngeluh ama malu yaa kak..". Melalui pernyataan ini pemimpin kelompok berusaha menstimulus anggota lain berpendapat dan meyakinkan bahwa yang memiliki keterbatasan saja mampu mandiri dan percaya diri dengan segala keadaan diri, apalagi seluruh responden secara fisik sempurna tak ada cacat, maka sebisa mungkin berusaha mengukir prestasi dan hal terpenting keenam responden harus berusaha hingga berhasil melewati bagian tersulit dalam hidupnya.

Evaluation dan tindak lanjut. Pertemuan Keenam. Pada pertemuan terakhir ini, pemimpin kelompok merangsang anggota kelompok untuk melihat perilaku beberapa waktu terakhir, setelah mengikuti kegiatan bimbingan kelompok. Semua anggota kelompok menyampaikan pendapat, dan mengaku bahwa anggota kelompok mulai semakin berani mengutarakan pandapat dalam kelompok dan berani maju ke depan kelas. Pada pertemuan ini pemimpin kelompok memberikan instrumen self-esteem kepada anggota kelompok sebagai data post test.

AP mengaku bahwa dirinya semula malu dan merasa rendah diri sebagai siswa baru pindahan dari Bogor, tetapi selama observasi peneliti sebagai pemimpin kelompok ia sudah tampak percaya diri dalam berpendapat. Pada pertemuan awal AP tampak tidak berani untuk menatap mata, semakin hari pada pertemuan keempat dan kelima
AP sudah mulai berani menatap mata dan meningkatkan volume suaranya. Begitu juga dengan DVN, DVN tampak pemalu dan cenderung lambat mengikuti instruksi, DVN sudah mulai berani menyampaikan pendapat meski volume suara bertahap meningkat. Tampaknya DVN butuh dilatih untuk maju ke depan kelas dan menjadi pemimpin kelompok.

FN sebagai anak kedua dari dua bersaudara, tampak belum mandiri dan percaya diri, kemajuan yang tampak pada FN ialah berkurangnya ucapan kasar dan tidak lagi melihat hasil orang lain terlebih dahulu saat ia berpendapat atau berkarya. Sepertinya diperlukan bimbingan khusus untuk FN, karena ia masih kesulitan menulis.

Sebagai anak kedua dari dua bersaudara, ELS tampak malu sekali ketika ia bercerita tentang orangtua ELS yang tidak memiliki pekerjaan. Diakui oleh diri dan temannya yang lain bahwa ELS tidak pernah melawan ketika ia diejek oleh teman sekelas. Pada satu sisi, ELS dinilai sebagai teman yang sabar namun bagi ELS ia butuh ruang untuk menampilkan emosi diri secara utuh. Kemajuan yang tampak pada ELS ialah ia mulai yakin bahwa dirinya sama baiknya dengan orang lain, hal ini tampak pada peningkatan capaian skor pada instrumen selfesteem.

RJL dan MR tampak sama-sama malu saat mereka bercerita tentang pekerjaan sang ayah dan kemampuannya yang kurang dalam akademik. Setelah mengikuti permainan dan menyaksikan tayangan "Nick Fujivic", MR mengakui bahwa ia bertekad untuk berlatih sepak bola lebih giat tanpa meninggalkan rajin belajar untuk meraih prestasi. Setelah diingatkan oleh anggota 


\section{Pengaruh teknik permainan pass the compliment dalam layanan bimbingan kelompok terhadap peningkatan self esteem siswa sekolah dasar-Sulistyani Puteri Ramadhani}

kelompok tentang kebiasaan MR sering bermain games online di warnet, MR mengakui sudah mulai mengurangi intensitas bermain games online di warnet.

Berdasarkan hasil pengamatan peneliti saat menjadi pemimpin kelompok tampak bahwa ada kemajuan pada sikap anggota yang menunjukkan bahwa anggota kelompok mulai dan semakin yakin saat membuat keputusan, mulai percaya diri, mandiri, dan realistis dalam percaya diri. Setelah peneliti mengolah data post test, peneliti memperoleh data bahwa memang terdapat kemajuan berdasarkan capaian skor data hasil post test masing-masing responden.

Hasil penelitian berdasarkan hasil uji hipotesis menunjukkan bahwa teknik permainan "Pass the Compliment dalam kegiatan bimbingan kelompok berpengaruh terhadap self-esteem siswa kelas VI SDN Manggarai 17 Pagi secara signifikan. Terdapat peningkatan self-esteem pada diri responden setelah diberi perlakuan bimbingan kelompok dengan teknik permainan "pass the compliment".

Sebelum diberikan perlakuan, seluruh responden penelitian berada pada kategori selfesteem yang rendah, namun setelah diberikannya perlakuan, terjadi peningkatan yang cukup signifikan pada responden. Seluruh responden tingkat self-esteemnya menjadi berada pada kategori sedang dan tidak ada yang berada pada kategori rendah serta tinggi. Hal ini tidak hanya mengandalkan data pre test dan post test saja, peneliti juga berkolaborasi dengan guru kelas untuk memastikan peningkatan self-esteem responden. Pengamatan dilakukan selama dua minggu pasca responden diberikan perlakuan.
Berdasarkan data observasi yang dilakukan oleh wali kelas sehari-hari, diperoleh data bahwa AP semakin sering menunjukkan rasa bangga atas hasil karya sendiri kepada guru, ia semakin sering datang ke sekolah tepat waktu dengan wajah yang ceria, semakin tampak proaktif dan berani meminta maaf jika telah melakukan kesalahan, dari sisi akademik AP cenderung semakin rajin berlatih. Hal yang tampak pada FN ialah cukup berkurang intensitas dalam mencontek dan tidak harus dimarahi terlebih dahulu saat hendak mengerjakan tugas. Meski ia masih bermain dengan teman yang sama, belum berani bersosialisasi dengan teman yang lebih tua FN sudah mulai berani untuk tampil ke depan kelas. Hal yang terjadi pada ELS adalah ia tampak senang ketika datang ke sekolah tepat waktu, namun ELS masih saja mencontek dan tampak takut berkata tidak' ketika teman-teman yang lain berkata 'iya'. Siswa yang rajin menulis ini tampak masih belum mampu cepat tangkap untuk memahami penjelasan guru. Sedangkan DVN tampak selalu berhati-hati saat berada dalam lingkungan baru, volume suara semakin besar sehingga agak terdengar dari sebelumnya tidak terdengar sama sekali, dan semakin cepat inisiatif untuk meminta maaf jika telah melakukan kesalahan.

Sebagai siswa yang sangat suka olahraga ini, RJL semakin tanggap melerai ketika ada teman yang bertengkar. Semula RJL tampak malu dengan latar belakang keluarga, tetapi RJL berhasil berani mengikuti perlombaan di sekolah. Intensitas RJL dalam menertawai teman yang sedang diejek semakin berkurang, meski terkadang masih terlihat RJL curang dketika 


\section{Pengaruh teknik permainan pass the compliment dalam layanan bimbingan kelompok terhadap peningkatan self esteem siswa sekolah dasar-Sulistyani Puteri Ramadhani}

bermain dengan teman di sekolah. Sama halnya RJL, MR mengakui malu dengan keadaan latarbelakang keluarganya, tetapi setelah kegaiatan bimbingan kelompok dengan teknik 'pass the compliment' ini tampak MR mulai rajin berlatih mata pelajaran dan mendapat nilai yang cukup baik. Meski masih tampak kecewa saat pendapatnya kurang didengarkan dalam kelas, MR sudah mulai berani maju ke depan kelas.

Hal ini dapat menunjukkan bahwa responden mulai mengembangkan penilaian positif terhadap diri dan tidak lagi merasa rendah diri dengan keadaan dan kemampuannya. Selain itu, responden mulai mampu menghargai kekuatan dan kelemahan diri serta yakin saat membuat keputusan secara mandiri meski kadang juga terdapat responden yang masih tampak tidak percaya diri saat menjawab soal ulangan, dan menyalahkan orang lain jika mendapatkan hasil kurang memuaskan. Sesuai dengan teori selfesteem menurut Nathaniel Branden, bahwa individu dengan self-esteem rata-rata atau sedang cenderung berubah-ubah, terkadang tidak konsisten dalam bertindak, terkadang bijaksana dan terkadang merasa diri merasa bodoh.

Permainan 'pass the compliment' ini memang memfasilitasi anak untuk mengembangkan self-esteemnya, namun juga dibutuhkan kerja sama dengan guru kelas, pihak sekolah dan terutama keluarga khususnya orangtua. Sebagian besar waktu keenam responden ada pada lingkungan keluarga, sehingga tidak hanya anak yang harus memahami dirinya berharga tetapi juga orangtua harus paham cara memperlakukan anak agar self-esteemnya tidak menurun lagi setelah diberikan perlakuan.
Kegiatan seminar atau diskusi dengan orangtua tentang cara mempertahankan atau meningkatkan self-esteem anak menjadi kegiatan yang seharusnya dilakukan untuk mendukung peningkatan, mempertahankan self-esteem keenam responden ini.

Seminar atau diskusi bertujuan untuk memberikan pemahaman kepada orangtua bahwa setiap anak itu unik, tidak bisa disamakan potensinya satu sama lain. Maka itu, orangtua harus paham betul potensi anaknya masingmasing berada dalam bidang apa. Jika orangtua sudah paham potensi anak, maka tidak akan ada lagi orangtua yang membandingkan anaknya dengan anak lain tentang kemampuan si anak, karena dengan membandingkan anak akan merasa inferior tidak lagi meyakini bahwa sebetulnya dirinya memiliki kemampuan yang dapat dibanggakan. Padahal bisa jadi anak tersebut memiliki potensi di bidang lain. Orangtua juga harus membiasakan memuji hasil karya anak tanpa melihat hasilnya, sehingga dapat menstimulus rasa percaya diri anak untuk mengembangkan potensinya dan dapat menghargai diri secara utuh.

Self-esteem memang tidak dapat terukur dan tampak secara kasat mata, seperti halnya jika siswa pandai matematika berarti siswa tersebut mampu mengalikan, menambah, mengurangi, dan membagi angka dengan cepat. Self-esteem yang rendah, sedang maupun tinggi dapat tampak melalui observasi, wawancara, dan alat ungkap data (instrumen). Self-esteem bisa jadi hal yang biasa saja atau tidak penting bagi seorang anak, tetapi menjadi sangat penting ketika anak sudah mulai memandang diri secara negatif bahkan 


\section{Pengaruh teknik permainan pass the compliment dalam layanan bimbingan kelompok terhadap peningkatan self esteem siswa sekolah dasar-Sulistyani Puteri Ramadhani}

merasa inferior. Bahkan untuk menentukan keputusan saja masih harus mengikuti orang lain, belum mandiri. Oleh karena itu, anak yang memiliki self-esteem rendah memerlukan bantuan layanan, dan layanan bimbingan kelompok dengan teknik permainan 'pass the compliment' dapat menjadi salah satu alternatif untuk meningkatkan self-esteem anak yang rendah.

Harus diakui bahwa bimbingan kelompok dengan teknik 'Pass the Compliment' memang berpengaruh terhadap peningkatan self-esteem siswa kelas VI SDN Manggarai 17 Pagi, namun bukan berarti keutuhan self-esteem ini hanya dipengaruhi oleh kegiatan bimbingan kelompok dengan teknik permainan 'pass the compliment saja. Faktor pola asuh orangtua, teman sebaya, gender, dan kelas sosial turut berkontribusi membentuk self-esteem seseorang, serta jika mengacu pada teori Branden bahwa self-esteem dipengaruhi oleh dua faktor yang bersifat intrinsik, yaitu daya tahan dan kesuksesan diri menguasai lingkungan secara wajar dan tanggung jawab pribadi.

Ada beberapa faktor yang menyebabkan bimbingan kelompok dengan teknik permainan 'pass the compliment' efektif dalam meningkatkan self-esteem. Faktor pertama, melalui teknik permainan "pass the complimenf responden memiliki kesempatan untuk mengenali, menyadari, dan menerima kelebihan dan kekurangan diri. Tidak mudah bagi anak usia sekolah dasar mampu menilai kelebihan dan kekurangan diri secara jujur, karena mereka cenderung meniru opini orang lain. Melalui permainan 'pass the compliment' ini, secara tidak langsung responden belajar menilai kelebihan dan kekurangan diri menurut diri sendiri tanpa harus meniru pendapat/penilaian orang lain. Selain itu, responden juga dapat belajar menerima penilaian kelebihan dan kekurangan diri berdasarkan sudut pandang orang lain. Hal ini senada dengan pemaparan Kathryn dan David Gerald, bahwa jika seorang anak disiapkan untuk menerima dan memiliki kekuatan serta keterbatasannya, anak selanjutnya akan cenderung menerima tanggung jawab untuk mengembangkan dan belajar memperbaiki dan mengelola keterbatasannya, menganggap bahwa dirinya yang bertanggung jawab atas perubahan dirinya.

Faktor kedua, ketika sudah berhasil menyadari dan menerima potensi diri hal yang dapat dikembangkan oleh responden melalui permainan 'pass the compliment ini ialah rasa percaya diri. Responden akan mendapat kesempatan untuk belajar semakin yakin saat menonjolkan potensi diri. Hal ini membantu responden untuk meyakini bahwa dirinya sama baiknya dengan orang lain, sehingga tidak perlu merasa rendah diri dan bertindak wajar dengan keberadaan dirinya.

Faktor ketiga adalah karena permainan ini berada pada setting kelompok kecil. Responden secara tidak langsung berlatih untuk berani bercerita di depan kelompok, nyaman saat berpendapat, memberikan dukungan pada sesama anggota kelompok. Melalui dinamika kelompok yang terjadi dapat membuat responden merasa bahwa dirinya dapat berperan dalam kelompok. Ditegaskan dalam buku Play Therapy with Adult (Chefer, 2003), bahwa melalui kelompok bermain dalam kondisi therapy mampu melatih kemampuan bersosialisasi kepada seluruh anggota 
2068 Pengaruh teknik permainan pass the compliment dalam layanan bimbingan kelompok terhadap peningkatan self esteem siswa sekolah dasar-Sulistyani Puteri Ramadhani

kelompok dan juga efektif dalam menumbuhkan ikatan psikologis dalam kelompok sepermainan. Melalui kelompok tidak hanya dapat memfasilitasi anggota agar dapat berlatih berinteraksi sosial secara sehat tetapi juga membantu responden merasa baik dan nyaman terlibat di dalamnya.

Ketiga faktor diatas memaparkan bahwa permainan 'pass the complimenf ini membantu responden untuk belajar bangga dan menghargai kelebihan dan kekurangan diri secara utuh serta mampu memandang diri sama baiknya dengan orang lain.

\section{SIMPULAN}

Terdapat pengaruh positif dari kegiatan bimbingan kelompok dengan teknik permainan 'pass the compliment' terhadap self-esteem siswa kelas VI SDN Manggarai 17 Pagi. Berdasarkan hasil uji hipotesis, diperoleh data bahwa: nilai asymp. Sig $=0,028<$ nilai Signifikan $\mathrm{a}=0,05$. $\mathrm{Hal}$ ini menunjukkan bahwa $\mathrm{H}_{0}$ ditolak, dan $\mathrm{Hi}$ diterima. Sehingga dapat dimaknai, terdapat pengaruh yang signifikan pada peningkatan selfesteem responden setelah diberikan perlakuan bimbingan kelompok dengan teknik permainan "pass the compliment

Terdapat peningkatan self-esteem pada diri responden setelah mendapatkan perlakuan (treatment) bimbingan kelompok dengan teknik permainan 'pass the compliment'. Berdasarkan hasil penelitian.

Dari enam responden yang termasuk kategori self-esteem cenderung rendah kemudian diberikan perlakuan bimbingan kelompok dengan teknik permainan "Pass the Complimenf mengalami peningkatan menjadi siswa dengan self-esteem cenderung sedang. Berdasarkan skor gain melalui teknik permainan 'pass the complimenf ini, peningkatan self-esteem responden termasuk kategori sedang dengan skor gain ternormalisasi sebesar 0,44 .

\section{DAFTAR PUSTAKA}

Albo,JM.,Nunezjl., Navarro, JG., Grijalvo.F. The Rosenberg Self-Esteem Scale: Translation and Validation in University Student. The Spanish Journal of Psychology 10, 2007, 458-467

AP, Sofwan, Daharnis, \& Syahniar, Efektifitas Layanan Bimbingan Kelompok dalam Meningkatkan Self-Efficacy Siswa. Jurnal llmiah Konseling Volume 2 Nomor 2, Juni 2013.

Azwar, Syarifudin, Penyusunan Skala Psikologi, Yogyakarta: Pustaka Pelajar, 2007.

Barber, Vicky, Creating Children's Art Games for Emotional Support, London and Philadelphia : Jessica Kingsley Publisher,2011.

Branden, Nathaniel, The Six Pillars of SelfEsteem, New York: Bantam Books, 1994.

Brown, Jonathan D., The Self, New York: McGraw Hill,1998.

Cattanach, Anna, introduction Play Therapy, New York: Brunner-Routledge, 2003.

C. J. Mruk, PhD, Self-Esteem Research, Theory, and Practice Toward a Positive Psychology of Self-Esteem, NewYork: Springer Publishing Company, 2006).

Coopersmith, Stanley, The antecendents of self esteem, San Fransisco: W.H. Freeman and company, 1967.

Departemen Pendidikan Nasional, 1997

Desmita, Psikologi perkembangan, Bandung: Rosdakarya, 2008. 
2069 Pengaruh teknik permainan pass the compliment dalam layanan bimbingan kelompok terhadap peningkatan self esteem siswa sekolah dasar-Sulistyani Puteri Ramadhani

Djiwandono, Konseling dan Terapi dengan Anak dan Orang Tua, Jakarta: Grasindo, 2005.

Drewes, Athena. A dan Charles E. Schaefer, School-Based Play Therapy (Second Edition), USA: John Wiley \& Sons, Inc, 2010.

Gerald, Kathryn dan David Gerald, Konseling Anak-Anak, Edisi Ketiga, Jakarta: PT.Indeks, 2012.

Gibson, Robert L. dan Marianne H. Mitchell, Bimbingan dan Konseling, Yogyakarta: Pustaka Pelajar, 2010.

Guindon, Mary H., Self-esteem across the lifespan : issues and interventions, New York : Taylor \& Francis Group, 2009.

Hepner. P. Paul, Research Design and Counseling, USA: thomson, 2008

Ketut Sukardi, Dewa dan Nila Kusumawati, Proses Bimbingan dan Konseling di Sekolah, Jakarta: Rineka Cipta,2008.

McMahon, Linnet, The Handbook of Ply Therapy, USA : Brunner-Routledge, 1992.

Melati, Rona, Skripsi: 'Pengaruh Teknik Permainan dan Bercerita dalam Layanan Bimbingan Kelompok terhadap peningkatan Keterampilan Sosial pada Siswa Kelas III di SDN Kalisari Petang', Jakarta: Universitas Negeri Jakarta, 2012

Muro, James J, dan Terry Kottman, Guidance and Counseling in the Elementary and Middle School, USA: WCB Brown\& Benchmark Publisher, 1995.

Prayitno dan Erman Amti, Dasar-Dasar Bimbingan dan Konseling, Jakarta:Rineka Cipta, 2009.

Prayitno, Layanan Bimbingan dan Konseling Kelompok (Dasar dan Profesi), Jakarta: Balai Aksara,1995.

R. Hake, Richard. Interactive Engagement Methods In Intrductory Mechanics
Courses, 1998, diunduh dari http://www.physics.indiana.edu/ sdi/IE $\underline{\text { M- 2b.pdf }}$

Rusmana, Konseling Kelompok Bagi Anak Berpengalaman Traumatis. Bandung: Rizqi Press, 2009

Rusmana, Permainan (Play \& Games) permainan untuk para Pendidik, Pembimbing, Pelatih, dan Widyaiswara, Bandung: Rizqi Press, 2009.

Santrock, John W, Life Span Development: Perkembangan Masa Hidup, Jilid 1, Jakarta: Erlangga, 2002.

Santrock, J.W., Perkembangan Masa Hidup jilid 2 terjemahan Achmad Chusairi,dkk., Jakarta: Erlangga,2002.

Schaefer, Charles E., Play Therapy with Adults, Canada : John Wiley \& Sons, Inc, 2003

Silalahi, Dr. Ulber, Metode Penelitian Sosial, Bandung : Refika Aditama, 2009.

Sugiono, Metodologi Penelitian Kuantitatif dan $R \& D$, Bandung : Alfabeta, 2013.

Sugiono, Metodologi Penelitian Pendidikan (Pendekatan Kuantitatif, Kualitatif, dan $R \& D)$, Bandung : Alfabeta, 2007

Sugiono, Metodologi Penelitian Pendidikan, Bandung : Alfabeta, 2008

Sugiono, Metodologi Penelitian Pendidikan, Bandung : Alfabeta, 2013

Sugiono, Statistika untuk Penelitian, Bandung : Alfabeta, 2007.

Suhardita, Kadek, Jurnal Skripsi: 'Efektifitas Penggunaan Teknik Permainan dalam Bimbingan Kelompok untuk Meningkatkan Percaya Diri Siswa pada SMA Laboratorium (Percontohan) UP! Bandung Kelas XF Bandung: Universitas Pendidikan Indonesia, 2011.

Tedjasaputra, Mayke S., Bermain, Mainan, dan Permainan, Jakarta: Grasindo, 2001. 
2070 Pengaruh teknik permainan pass the compliment dalam layanan bimbingan kelompok terhadap peningkatan self esteem siswa sekolah dasar-Sulistyani Puteri Ramadhani

Yusuf, Syamsu, Psikologi Perkembangan Anak dan Remaja, Bandung: Rosdakarya, 2011.

KBBI, Kamus Besar Bahasa Indonesia, Departemen Pendidikan dan Kebudayaan, Jakarta: Balai Pustaka, 1989. 